\section{New Tropical Fungi}

THE various regions of Central Africa are a territory which has not been studied mycologically in any detail. It is therefore not surprising that, in a second paper on tropical fungi, G. B. Hansford (Trans. Linn. Soc. Lond., 159, pt. 1, pp. 21; 1947), in describing thirty-four species, includes no less than twentyeight new ones. The genus Meliola is well represented with eight new species, and it has been found necessary to create two new genera, Phragmodiscus and Dictyoasterina, to accommodate some of the new findings. The collections are from Uganda, the Belgian Congo and Sierra Leone.

\section{University of Leeds}

THE Council of the University of Leeds has announced that the Wool Industries Surplus Cloth Corporation, Ltd., has given a sum of $£ 40,500$ for the establishment in the University of a research chair of wool textile engineering within the Department of Textile Industries. Other gifts include $£ 10,000$ from the International Wool Secretariat (in addition to a similar amount already received) for the purpose of completing the cost of equipping the new Wool Research Laboratories; 1,000 dollars from the Ella Sachs Plotz Foundation for the purchase of equipment for the Department of Biochemistry; $£ 250$ from Messrs. J. and J. Crombie of Aberdeen, for the Textile Department; £2,126, handed over by the Leeds Public Dispensary and Hospital, being the balance of the Research Appeal Account, which the Council agreed to earmark for rheumatism research ; $£ 300$ a year from Sandoz Products, Ltd., of Bradford, to provide a scholarship for a male candidate to take the form of three consecutive two-year awards ; 500600 plastic mouldings for experimental research in speech training, presented to the Department of Education by Messrs. Birkby's, Ltd., of Liversedge.

\section{University of London: Appointments}

THE following appointments in the University of London have been announced: Dr. D. V. Glass, reader in demography at the London School of Economics and Political Science, to the University chair of sociology tenable at the School; Mr. E. P. Sharpey-Schafer, physician and senior lecturer at the Postgraduate Medical School of London, to the University chair of medicine tenable at St. Thomas's Hospital Medical School ; Dr. D. S. Bertram, lecturer in the Department of Entomology and Parasitology in the Liverpool School of Tropical Medicine, to the University readership in entomology tenable at the London School of Hygiene and Tropical Medicine; Dr. F. L. Warren, senior lecturer in biochemistry in the Physiology Department of St. Mary's Hospital Medical School, to the University readership in biochemistry tenable at University College. All these appointments take effect on October 1, 1948.

The titles of emeritus professor in the University have been conferred on the following: Prof. A. B. Appleton, on his retirement from the chair of anatomy at St. Thomas's Hospital Medical School; Prof. O. L. V. de Wesselow, on his retirement from the chair of medicine at St. Thomas's Hospital Medical School ; Prof. F. E. Fritsch, on his retirement from the chair of botany at Queen Mary College ; Prof. D. T. Harris, on his retirement from the chair of physiology at the London Hospital Medical College; Prof. T. Baillie Johnston, on his retirement from the chair of anatomy at Guy's Hospital Medical School ; Prof. W. Neilson
Jones, on his retirement from the Hildred Carlile chair of botany at Bedford College.

The following doctorates have been conferred: D.Sc. : J. R. Busvine (Imperial College of Science and Technology); D.Sc.(Eng.): D. G. Tucker (external student).

\section{Beit Memorial Fellowships for Medical Research}

THE following elections have been made by the Beit Memorial Trustees: Senior Fellowship ( $\$ 900$ a year): Dr. F. Sanger (Cambridge), to study the struc. ture of proteins with special reference to insulin, at the Department of Biochemistry, University of Cambridge. Junior Fellowships (normal value $£ 600$ a year): D. A. Darcy (Dalhousie, Canada), to study the role of the lymphocyte and plasma cell in homograft breakdown, at the Department of Zoology and Comparative Anatomy, Oxford; R. M. C. Dawson (London), to study biochemical changes in the brain associated with different forms of functional activity, at the Biochernical Laboratories, Cardiff City Mental Hospital ; F. N. Fastier (New Zealand), to study the nature of the musculotropic action of basic amidine derivatives, at the Department of Pharmacology, Oxford; Dr. L. J. Haynes (London), to study the synthesis of the coenzyme, cozymase, at the University Chemical Laboratory, Cambridge; Dr. A. T. James (London), to study the relationship between structure and biological activity in naturally occurring substances, at the Lister Institute of Preventive Medicine, London; A. McCoubrey (London), to study analgesic and addictive tendencies from a chemical point of view, at the Departments of Organic Chemistry and Pharmacology, University of Leeds ; S. W. Stanbury (Manchester), to study the effect of changes in nervous activity, induced by narcosis and sleep, on the renal circulation and blood pressure in normal and hypertensive individuals, at the Department of Medicine, University of Manchester; D. Verel (Cambridge), to study the postural hypotension which may follow prolonged rest in bed, at the Clinical Research Unit, Guy's Hospital, London.

\section{Announcements}

THE Joint Committee consisting of representatives from the Royal Society of Edinburgh, the Royal Physical Society, and the Royal Scottish Geographical Society have awarded the Dr. W. S. Bruce Memorial Prize to Dr. W. A. Deer, Department of Mineralogy and Petrology, University of Cambridge, for his work in East Greenland during 1935-36, especially in regard to the petrology of the Skaergaard gabbro intrusion.

THE Faraday Society is arranging a general discussion on "The Physical Chemistry of Process Metallurgy" to be held at Ashorne Hill, near Leaming. ton Spa, by permission of the British Iron and Steel Federation, during September 23-25. Further particulars can be obtained from the Secretary, Faraday Society, 6 Gray's Inn Square, London, W.C.1.

THE postgraduate lectures for 1948 of the London Section of the Oil and Colour Chemists' Association will be delivered by Prof. H. J. Emeléus, on September 30, October 7 and 14 at 6.30 p.m., at the Royal Institution. Prof. Emeléus will speak on "The Impact of Radioactivity on Inorganic Chemistry". Admission will be by ticket (price 10s.) obtainable from the honorary secretary of the London Section of the Association, H. C. Worsdall, c/o Messrs. Plastanol Ltd., Crabtree Manorway, Belvedere, Kent. 